\title{
A new locality for the lion-tailed macaque
}

\author{
Brian Groombridge
}

The author, who initiated a recent search that led to the rediscovery of the rare cane turtle in south-west India (see Oryx, July 1983), recently returned to the Anaimalai area. With the help of Kadar tribal people he found a group of liontailed macaques a little outside their known range - a discovery that assumes significance when one considers that it is one of the world's most endangered primate species.

There has been much concern expressed recently over the relatively poor survival prospects of the lion-tailed macaque Macaca silenus. This species, endemic to tropical moist forest regions in the Western Ghats hills of south-west India, is described as an 'Endangered' species in the IUCN Red Data Book for Mammalia (Holloway, 1976), and may be one of the world's most endangered primate species. Green and Minkowski (1977), on the basis of extensive fieldwork in 1973-75, considered the species to be on the verge of extinction. In these circumstances even a small extension to the known range assumes some significance.

The northernmost confirmed locality for liontailed macaques is in the North Kanara district of west Karnataka (Bhat, 1983). To the south, groups are known at a very few other sites in south-west Kamataka, also in the south-west Nilgiris (Kerala), and (south of the Palghat-Gap) at several sites scattered along the upland axis extending from the Nelliampathi Hills and Anaimalai Hills proper in the north, to the Ashambu Hills (Kerala/Tamil Nadu) near the southern tip of the subcontinent (Ali, 1982; 144

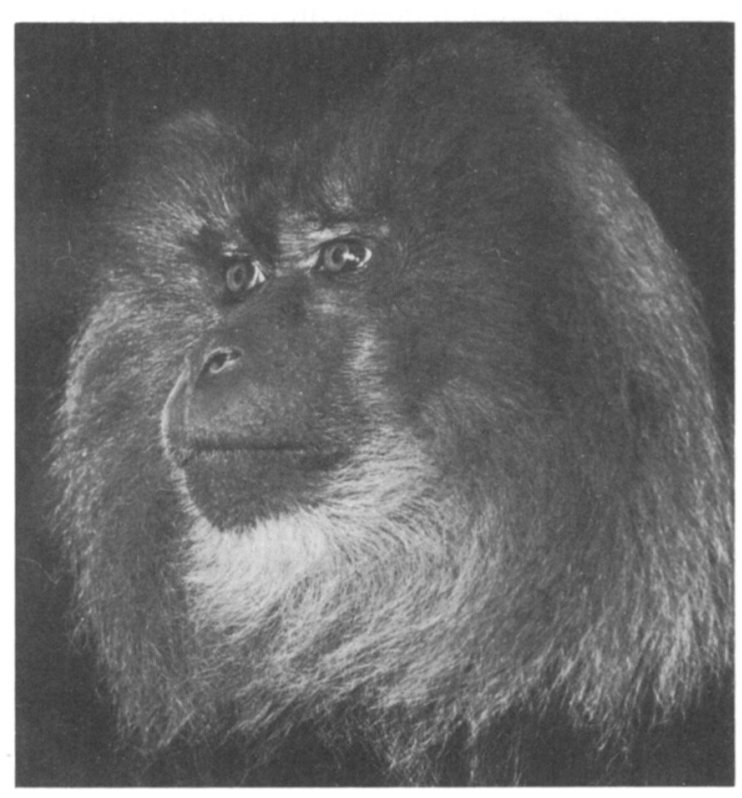

Male lion-tailed macaque (Michael Lyster/Zoological Society of London).

Green and Minkowski, 1977). The Ashambu range, notably the Kalakkad Sanctuary, includes the last real stronghold of the species with the Silent Valley area of the south-west Nilgiris a close second.

Two recent population estimates are of a similar order of magnitude: Green (1983b) suggests approximately 600 individuals in partly protected populations, potentially viable over the long term, with perhaps twice that number in total (i.e. including probable non-viable groups); Ali (1982) suggests a minimum number of 670 animals in 61 different groups.

Oryx Vol $18 \mathrm{No} 3$ 


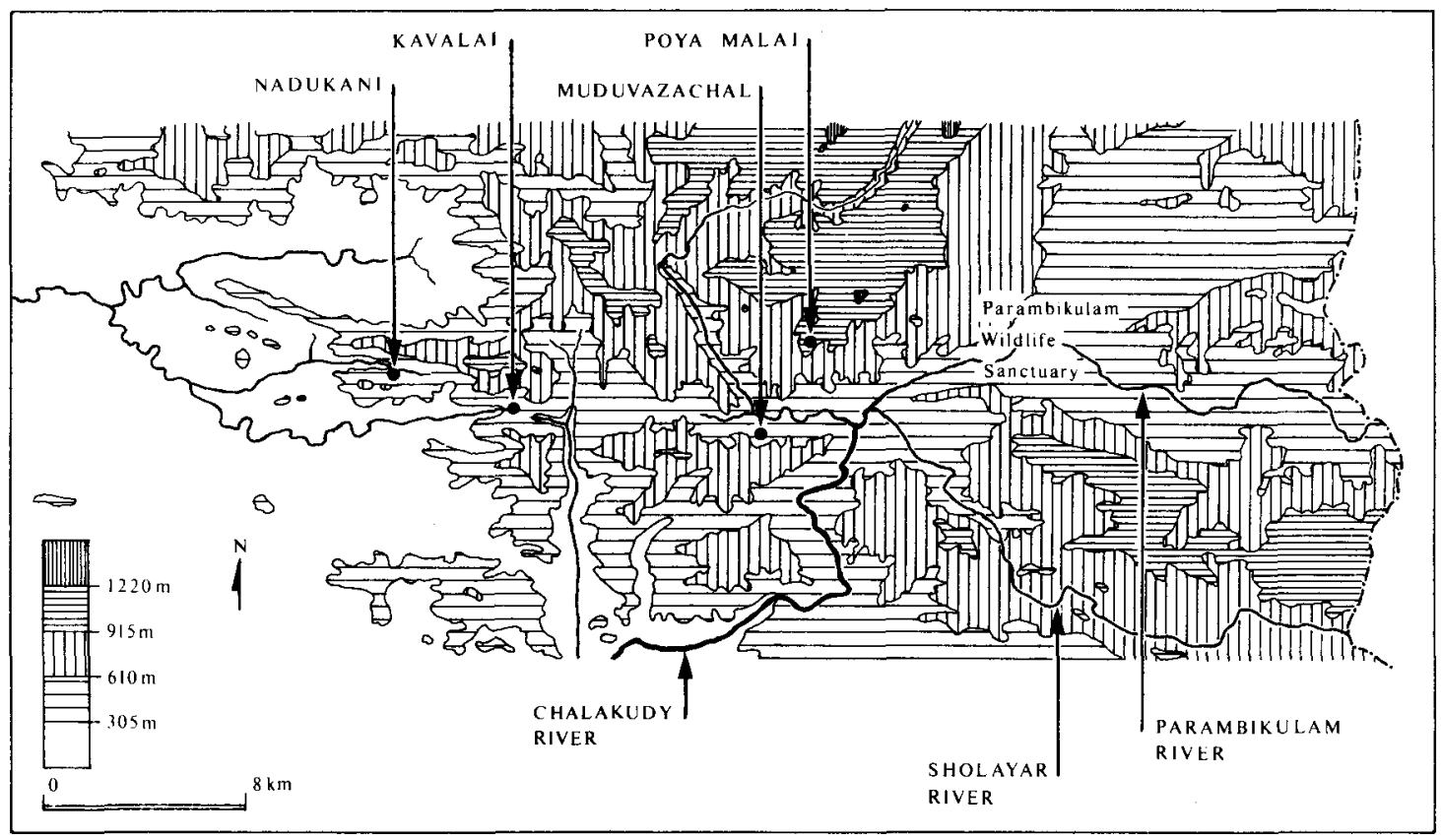

\section{Observations}

I report here the sighting of a small group of at least five, and probably eight to 10 , individuals at a locality in the Trichur District of Kerala State, in the extreme north-west of the Anaimalai Hills, fringing an area often known as the Nelliampathi Hills.

These animals were discovered, on the basis of information provided by Kadar tribals, in a valley that may loosely be termed 'Nadukani'. In fact Nadukani (= 'bird's eye view') is the name given to an area of rock outcrops, with a large rock shelter, high on the northern side of the valley. Nadukani is situated about $3 \mathrm{~km}$ west of Kavalai and the mountain known as $\mathrm{Pu}$ Malai (or $\mathrm{Pu}$ Mudi), and a similar distance north of the former Parambikulam-Chalakudy forest tramway.

This site is to the west of the nearest previously reported locations for $M$. silenus. These are, firstly, a cluster of sites (Chempadi para, Koorankuzhi, Muthala vayali) about $16 \mathrm{~km}$ east of Nadukani, on the slopes of the mountain Poya Malai, just north of the Parambikulam River (Easa and Balakrishnan, 1983); secondly, the Sholayar
Nelliampathi Hills_ north-west Anaimalai area, where the new sightings of lion-tailed macaques were made.

area, where troops of about 10 individuals each have been seen on three occasions (Vijayan, 1978). Between four and nine (plus) lion-tailed macaques have been seen at each of the former cluster of sites (Easa and Balakrishnan, 1983), all within the Parambikulam Wildlife Sanctuary; Sholayar adjoins the Sanctuary to the south. Other troops have been reported further to the east inside the Sanctuary (Easa and Balakrishnan, 1983; Sugathan, 1981; Vijayan, 1978), which holds a minimum of 24 lion-tailed macaques. The species has been recorded (Oates, 1975 communication cited by Green and Minkowski, 1977) in a zone of active selection felling in the valley of the Chalakudy river; the site was not specified but was very probably in the headwaters of the river, also in the Parambikulam-Sholayar area.

Nadukani, a steep-sided and relatively secluded valley, about $4 \mathrm{~km}$ long, appears to hold the most westerly surviving patch of evergreen-semievergreen moist forest in the Nelliampathi-Anaimalais 


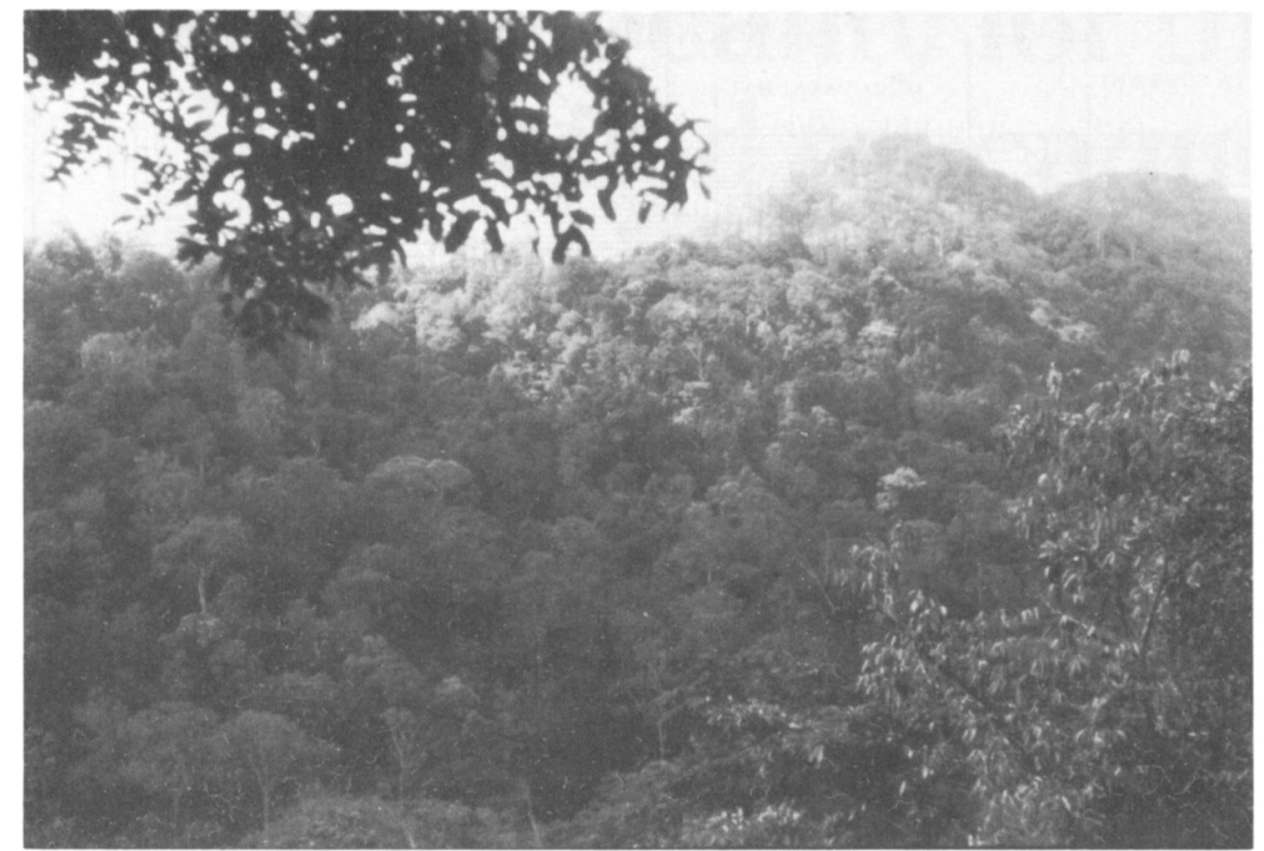

View from $\mathrm{Pu}$ Malai westward along Nadukani Valley. The lion-tailed macaques were seen on the south ridge of the valley (Brian Groombridge). region. Although not entirely untouched, it still supports many reptile, bird and mammal species characteristic of the Western Ghats forests, and was the site of rediscovery of wild populations of the rare endemic cane turtle Heosemys silvatica (Groombridge et al., 1983). Another notable mammal species, present in small numbers, is the Nilgiri langur Presbytis johnii, considered a 'Vulnerable' species in the Red Data Book; one bird species of concern seen at Nadukani is the great pied hornbill Buceros bicomis.

One day, which proved fruitless, was spent attempting to search the entire valley for liontailed macaques; a second day (29 November 1983) was devoted to a slow and systematic survey of the north-facing slope of the valley (i.e. the southern ridge). The group was located in mid-afternoon, initially by the sounds of movement in the canopy and of a steady rain of discarded food items, and then visually. They were feeding high in a very large fig tree (Ficus, species undetermined) bearing ovoid yelloworange fruits about $3 \mathrm{~cm}$ long, many of which were discarded only partly consumed. An intermittent low crooning or moaning could be heard among feeding animals. Five individuals were actually seen at one instant, but, on the basis of sounds made simultaneously by unseen animals, I estimate the group to have comprised at least eight, and possibly 10 , individuals in total.

At least one of the animals seen may have been a reproductive male; it was somewhat larger than the others, possibly darker, with a longer facial ruff, and a more prominent distal tuft on the tail. The group kept to the canopy of the highest trees and was extremely difficult to observe closely; it moved rapidly away once it had obviously become aware of my presence, which may well reflect wariness associated with hunting pressure. The lion-tailed macaques were much less vocal than Nilgiri langurs seen in nearby forest, and also moved much more quietly, walking nimbly along canopy branches, or dropping quietly from one level to another, rather than running, jumping and 'crash landing' like the langurs. On a subsequent occasion in early December my colleague saw four adult and two juvenile lion-tailed macaques, also a 'big' troop of Nilgiri langurs and a group of bonnet macaques $M$. radiata, all within about $300 \mathrm{~m}$ of each other on the higher peak of the south ridge (Vijaya, 1983). 


\section{Discussion}

The Kadars at Nadukani reported that lion-tailed macaques were formerly seen there in significantly greater abundance, but since a motorable track was cut into the valley three years ago, the species had deserted the area and was only now being seen again. The track, constructed mainly by blasting with dynamite, was cut to facilitate extraction of bamboo. Desertion was probably due to general disturbance and to increased hunting pressure (both Nilgiri langurs and lion-tailed macaques are in demand for food in nearby villages, partly for reputed medicinal properties).

Our Kadar informants also reported that more than one group can sometimes be found at Nadukani (it could not be established whether more than one group are permanently present in the area), and that groups are regularly encountered at Kavalai and eastward at Muduvazachal. These two sites effectively fill in the 16 $\mathrm{km}$ gap between Nadukani and the nearest locations reported in the literature, in Parambikulam Wildlife Sanctuary to the east. Lion-tails also occur in the Anaimalais Wildlife Sanctuary, contiguous with the Parambikulam Sanctuary but further to the east, within Tamil Nadu State. There are still some relatively good stands of evergreen and semievergreen moist forest along this west-east valley axis, and it appears feasible that groups of lion-tailed macaques could move along this corridor. Green (1983a) has suggested that a rain forest corridor about $0.5 \mathrm{~km}$ wide at a minimum can allow either wandering individual reproductive males, or small groups, to move and colonise depleted regions (if not separated by more than a few kilometres).

I believe the Kadars' reports concerning $M$. silenus to be reliable, both the apparent desertion and recolonisation of Nadukani, and their sightings to the east of Nadukani, since all their other wildlife information proved totally accurate whenever a check was possible.

Nadukani and the forested valley corridor to the east are still poorly known zoologically; it is quite possible that lion-tailed macaques move through more regularly, or are resident in greater numbers, than available evidence suggests. If Nadukani and the valley corridor linking it with the Parambikulam-Anaimalai Sanctuary area can be maintained in their present condition, the chances for the continued survival of lion-tailed macaques in the region would be very much enhanced. One clear priority is to prevent further bamboo extraction in Nadukani, planned to take place in a few years time when the present growing stock will have matured.

\section{Acknowledgments}

This report arises from a recent project, carried out in cooperation with the Madras Crocodile Bank, concemed primarily with the herpetofauna of the Nadukani area and resource utilisation by Kadar tribals. A general report on the recent fieldwork is in preparation.

I am grateful primarily to the ffPS and the Species Survival Commission of IUCN whose support made fieldwork in the Anaimalais possible; to Ms J. Vijaya (Research Officer, Madras Crocodile Bank) for translation and other assistance; to Chandran, his family and others for tolerating my frequent questions about the life and environment of Kadar tribals; and to officials of the Kerala Forest Department for allowing me to visit this reserve forest area.

\section{References}

Ali, R. 1982. An overview of lion-tailed macaque status and distribution. Paper presented at Intemational Symposium on Liontailed Macaques, Baltimore, Maryland, 19-22 May.

Bhat, H.R. 1983. Lion-tailed macaque in Karnataka. WWFIndia Newsletter, No. 44, p. 9.

Easa, P.S. and Balakrishnan, M. 1983. Population ecology and management problems of larger mammals in the Parambikulam Wildlife Sanctuary, Kerala. Paper presented at Bombay Natural History Society Centenary Seminar, Bombay, 6-10 December.

Green, S. 1983a. Macaca silenus: many small sanctuaries or fewer large ones?-factors affecting the design of species preserves. Paper presented at Bombay Natural History Society Centenary Seminar, Bombay, 6-10 December.

Green, S. 1983b. Pers. comm., Bombay, 6-10 December.

Green, S. and Minkowski, K. 1977. The lion-tailed monkey and its south Indian rain forest habitat. In Primate Conservation, pp. 289-337 (Eds H.R.H. Rainier III and G.H. Bourne). Academic Press, New York

Groombridge, B., Moll, E.O. and Vijaya, J. 1983. Rediscovery of rare Indian turtle. Oryx, 17(3), pp. 130-134.

Holloway, C. 1976. Data sheet for lion-tailed macaque. In IUCNRed Data Book, Vol. 1, Mammalia. IUCN, Morges.

Sugathan, R. 1981. A survey of the Ceylon Frogmouth (Batrachostomus moniliger) habitat in the Westem Ghats of India. J. Bombay nat. Hist. Soc. 78(2), pp. 309-316.

Vijaya, J. 1983. In litt., 17 December.

Vijayan, V.S. 1978. Parambikulam Wildlife Sanctuary and its adjacent areas. J. Bombay nat. Hist. Soc. 75(3), pp. 888 900.

Brian Groombridge, IUCN Conservation Monitoring Centre, 219(c) Huntingdon Road, Cambridge CB3 ODL. UK. 